\title{
6 The nature of perceived safety in rural areas
}

Imagine that some farmers declare they are worried about having their livestock stolen. Should this be enough to influence crime prevention efforts by the local police force? Or consider the case of a woman who is in fear because of constant threats from her violent partner. Should her fear be taken seriously by workers in social services or the police to avoid something more serious happening?

Fear of crime is not typically considered a conventional policing matter and seems to be even less of an issue in rural communities. One reason for this neglect is that the police, as well as those who devote their time to crime prevention, often work reactively, requiring an offense to be committed before any action can be taken. Another problem is that fear (of crime) may be triggered by the trauma of victimization, though that is not its only source. Anxieties are fed by multi-scale factors. This chapter examines how the multifaceted nature of fear makes perceived safety a difficult issue to tackle. Instead of denying such complexity, this chapter attempts to provide examples of how such anxieties form and are associated with the fear of crime in rural environments in Sweden. "Perceived safety" is a general concept used in this chapter to characterize both fear of crime and other overall anxieties, often measured by safety and crime victims' surveys.

Lack of perceived safety - or, more specifically, fear of crime - has been the subject of interdisciplinary research for many decades, but the results are far from unproblematic. Crime victims' surveys and interviews are often the basis of this type of research, which has been criticized for offering a shallow picture of what fear is actually is. This chapter examines fear as an informative resource that may improve quality of life for those living in rural communities. If fear is a reflection of everyday life experiences, what are those experiences in rural communities?

\section{The nature of perceived safety in rural areas}

Rural areas are regarded worldwide as relatively safer environments than urban areas (Barclay, Scott, Hogg, \& Donnermeyer, 2007; Bradford \& Myhill, 2015; BRÅ, 2011; Ceccato \& Dolmén, 2013; Donnermeyer \& Kreps, 1986; Maxfield, 1984; Shappland \& Vagg, 1985). Despite this widespread belief, research has 
also found that this apparently homogeneous pattern of safety in rural areas does not hold up to scrutiny. Fear and other types of anxiety are as much an issue in rural areas as they are in big cities or, at least, are for some groups of individuals at particular times (Panelli, Little, \& Kraack, 2004). The literature suggests that people in rural towns are not actually fearful of crime itself but are concerned with what they perceive as a threat to their rural idyll (Marshall \& Johnson, 2005). Power relationships in the community may trigger fear, at least for some by some (Hunter, Krannich, \& Smith, 2002; Scott, Carrington, \& McIntosh, 2012; Yarwood \& Gardner, 2000). Thus, the nature of perceived safety (or the lack thereof - fear) is a phenomenon affected by multi-scale factors (Day, 2009; Los, 2002; Wyant, 2008). Some factors are local and tangible, whilst others may be more difficult to assess but still affect individuals' anxieties at the local level. Fear can be multidimensional, as an individual can fear for oneself (personal fear) and fear for others (e.g., children, spouses, friends) whose safety the person values.

Fear is, according to Warr (2000, p. 453), "an emotion, a feeling of alarm or dread caused by awareness or expectation of danger." If one concentrates on looking at "fear of crime" only, Ferraro $(1995$, p. 8$)$ defines it as "an emotional reaction of dread or anxiety to crime or symbols that a person associates with crime." Thus, an increase in crime would hypothetically affect perceived safety. However, this simplistic causal relationship is rarely confirmed by empirical studies, as the fear of crime refers to the fear of being a victim of crime as opposed to the actual probability of being a victim of crime, that is, the actual risk (Hale, 1996). As Pain (2009) suggests, the concept of fear of crime has less significance than is widely expected. Yet, its construct, as it is argued here, can be informative in the context of perceived safety in rural context.

Furstenberg (1971) was one of the first researchers who recognized the difficulty in distinguishing between concern about and fear of crime. Concern about crime, the author suggests, is an estimation of the seriousness of crime as a public issue, while fear of crime is the perceived risk of victimization. The author found that concern and fear of crime were not significantly related to each other: concern with crime was associated with resentment to social change, while fear of crime was not related to attitudes toward social change, and therefore these were not interchangeable concepts. Later, Lotz (1979) has suggested that concern about crime is related to a variety of individuals' politically conservative attitudes. Still, not everyone agrees with these explanations and the conceptual differences.

Previous research has shown that an individual's fears depend on his/her individual characteristics, such as physical abilities, age, gender, socioeconomic status, and ethnic background (Box, Hale, \& Andrews, 1988; Garofalo \& Laub, 1979; Pain \& Smith, 2008). Individual factors play an important role in defining perceptions of risk and safety. Gender and age are perhaps the strongest ones.

The individual dimension of fear is often related to the vulnerability hypothesis, in which those perceiving themselves as vulnerable are likely to be more fearful. 


\section{Gender}

Traditionally, women are portrayed as being more fearful than men about their personal safety (Box et al., 1988; Koskela, 1999; Loukaitou-Sideris, 2004). This degree of fear by women is higher in public places than in domestic settings. One of the reasons for these unbalanced levels of fear is that women and men are victimized in different places. Regardless of which part of a city a woman lives in, her home tends to be more dangerous than any outdoor environment. For example, although the majority of rapes are committed indoors by someone the victim knows (e.g., a partner or parent), the international literature on sexual violence indicates that rape in public places is the one that feeds the idea of public places as dangerous places (Canter \& Larkin, 1993; Ceccato, 2014; Pyle, 1974). It has also been suggested that women are more fearful because of their physical and social vulnerabilities (Furstenberg, 1971; Gray \& O’Connor, 1990; Jackson \& E. Gray, 2010; Skogan \& Maxfield, 1981).

In one of the seminal studies in this area, Valentine (1990) finds that women anticipate being at risk in several specific public settings (e.g., bus stops, open spaces, alleys, underground passages) than in the domestic arena. Gender differences in stated personal safety may also be related to the fact that women and men are traveling in different ways or spending time in different places (Kunieda $\&$ Gauthier, 2007). However, gender is not the only factor that affects perceived safety. For instance, Bromley and Nelson (2002) find significant gender differences in the perceived safety of boys and girls in the city center environment (e.g., where many transportation nodes are located) but no difference in perceived safety in their home areas.

\section{Age}

Research also finds that feelings of insecurity typically increase with age, partly because of the inevitable increase in individuals' physical and/or mental vulnerability. Previous research has shown that while young people are statistically more at risk of being victimized, older and/or disabled individuals tend to be more fearful (Furstenberg, 1971; Lagrange \& Ferraro, 1989). Sweden is not an exception (Hayman, 2011). Those who feel that they have one or more disabilities experience more anxiety and fear of being a victim to crime and avoid going out (City of Stockholm, 2011). In Sweden, although the elderly represent only 18 percent of the population, more than two-thirds of all fatal accidents occur among them; more than half of these accidents take place around their homes (Torstensson, Forslund, \& Tegnell, 2011). Many people stop using public transportation when they get older, even in small municipalities. Wretstrand and Svensson (2008) show that 46 percent of elderly people interviewed refrain from taking the bus because they are afraid of traveling alone.

Vulnerability interacts with other factors to determine an individual's perceived safety. For example, new evidence shows perceived vulnerability to be the strongest predictor and mediator of the relationship between perceived disorder in a place 
and perceived safety (Acuña-Rivera, Brown, \& Uzzell, 2014). The authors indicate that the more disordered a place is perceived to be, the more a person relies on the perception of risk to estimate how safe she/he might be. A relevant question here is, safety for whom? Homeless people temporarily parked in a central station may be perceived as threats by the local inhabitants, while the itinerants themselves are frightened by the lack of familiarity and the anonymity of transients. Overall, factors in the local social environment were found to be more important as drivers of fear of crime (including values, social networks, and familiarity) than the physical environment in a qualitative study by Lorenc et al. (2013).

\section{Previous victimization}

Among the individual factors, prior victimization (or awareness of others' victimization) is often considered a determinant of a person's fear. Current perceived safety in both urban and rural areas may be affected by the experience of having been a victim of a crime, for example, having been robbed, subjected to intimidation, or assaulted. Experiencing or witnessing other people's victimization (particularly someone close, family, or friends) may also affect an individual's level of personal safety (for a review, see e.g., Skogan, 1987). However, previous studies show ambiguous links between victimization and fear of crime (Cates, Dian, \& Schnepf, 2003; Garofalo \& Laub, 1979), as its effect on people's behavior and attitudes may be moderated by other factors. At the community level, rural communities with relatively little crime may express high levels of fear because of occasional serious crimes, such as homicide. These "rare events" can disproportionately affect rural residents' fear of crime. Physical isolation may also lead to a disproportionately high declared fear of crime because of individuals' relative vulnerability. For example, rural farm residents are more sensitive to risk than are their counterparts living elsewhere (Bankston, Jenkins, Thayer-Doyle, \& Thompson, 1987).

\section{Physical environment}

Fear (of crime) is a reflection of what one sees and perceives with one's senses. Fear is a function of an individual's emotional reactions to a place and memories and associations that a place brings to the surface. In rural contexts, forests, parking lots, and service stations along roads and other desolated areas in a rural village may generate fear among visitors to a small village but may be just the place that young people treasure the most, as they can gather and spend time free from adult supervision. In other words, fear is a feeling produced by the social constructs of a physical space. Skår (2010), for instance, illustrates how feelings of a forest (in Norway) are dynamic in terms of gender and explores how men and women experience - and respond to - feelings of fear and anxiety in nature. 


\section{Signs of disorder and crime}

Lack of clearly defined private-public spaces is said to affect perceived safety (Newman, 1972). At the same time, barriers and the construction of fortresses around buildings can create, at least in urban areas, geographical disruption and generate suspicion and fear (Landman, 2012). Thus fear of crime goes beyond buildings and streets. It is sometimes regarded as a reflection of the state of the community, and the meaning attached to an environment at a particular time.

Social interactions that occur at certain places may also lead to lack of perceived safety, around bars or transport nodes, for instance. The mechanisms linking visible deterioration to a fear of a place can be likened to the Wilson and Kelling's broken window syndrome (Wilson \& Kelling, 1982), which suggests that unrepaired damage to property encourages further vandalism and other types of crimes. They indicate that acts of vandalism and public disorder function as symbols of the extent to which an area is in decline. Signs of physical deterioration are also thought to be more important determinants of fear of crime than the actual crime itself. Signs that nobody has control - abandoned buildings, litter, vandalism, and loitering - are thought to trigger fear of crime (Lewis \& Maxfield, 1980) and are indicators of more serious crimes. As Skogan (1996) suggests, this is not only because signs of physical deterioration are often visible but also because they are able to capture a much broader range of problems and are therefore more informative to residents than official crime statistics. Public perceptions of disorder have also been linked to implicit stereotypes about race and deprivation (Sampson \& Raudenbush, 2004) and, at least in urban areas, they help perpetuate segregation and suspicion among groups. Rural areas are not as immune to physical deterioration as the literature would suggest (LaGrange, Ferraro, \& Supancic, 1992), quite the opposite, signs of disorder and crime often translates into a differentiated rural housing market (Wilhelmsson \& Ceccato, 2015).

\section{Mobility patterns}

Fear can be affected by the way people travel and the environments to which they are exposed. The simple decision one takes to leave home implies a change in one's safety status (increase or decrease), depending on how and when one moves (Ceccato, 2013). People's fears and risk perceptions are determinants for the kinds of risk they can accept to be exposed to (Fyhri \& Backer-Grøndahl, 2012). In rural areas, particularly in the most remote ones, long distances separate people's homes from their work and basic services. Recent changes in the Swedish regional market have imposed more frequent and longer commutes. These are often onerous for individuals: men still travel further to work than women, but both spend a similar amount of time commuting, which has implications for gender equality (Bergström, 2008; Gil Sola, 2010).

\section{Familiarity}

Newcomers may feel unsafe if they do not know an area. Valentine (1990) suggests that, in the absence of prior experience or familiarity with a particular 
place, judgment is likely to be based on preconceived ideas about similar settings and their occupants. This familiarity can also be linked to the individual's social context and norms. Rural residents moving to large urban centers may feel unsafe, at least for some time, by the fact that such places offer anonymity that may be perceived as a threat. Milgram (1974, p. 46) suggests that anonymity can vary, from total anonymity, to full acquaintance, and that the various degrees of anonymity may influence how individuals feel in cities and towns. For example, "conditions of full acquaintance offer security and familiarity but they may be stifling because an individual may be caught in a web of established relationships" and expected behaviors, sometimes unknown to the outsider. Panelli et al. (2004) also contest constructions of the rural community as an emotionally harmonious, safe, and peaceful space by exposing women's experiences of fear in various rural communities in New Zealand.

\section{Social cohesion and collective efficacy}

Perceived safety relates to the social environment an individual may encounter. Places characterized by strong social ties and cooperative behavior (social cohesion) are often associated with high perceived safety. Social relationships in rural communities are traditionally thought to be based on networks of personal ties that perpetuate over time, while in urban areas social networks are thought to be less stable. This echoes the popular cultural oppositions between the city as the site of an artificially imposed order and the country as a naturally ordered, bonded, and cohesive community. The dichotomy between gemeinschaft and gesellschaft (Tönnies, 1887) provides a framework for potential urban/rural differences in terms of social ties and cooperative behavior. In certain cases, this active engagement leads to collective efficacy (Sampson, Morenoff, \& Felton, 1999). Cancino (2005) shows evidence that the differential ability of residents to realize mutual trust and solidarity (i.e., social cohesion) is a major source of variation in citizens' perceived safety in a non-metropolitan area in Michigan. Safety is a reflection of patterns of assistance and protection within groups regardless of whether the members reside in rural or in urban areas (Hofferth \& Iceland, 1998; Milgram, 1974). In practice, criticisms of the effect of strong ties in communities suggest that strong social networks strengthen communities but may also have the unintended effect of "enabling" exclusion and other types of harmful behavior (DeKeseredy \& Schwartz, 2008).

\section{Othering}

Fear (and other anxieties) may also result from the overall sense of change that a place is undergoing. Rapid changes in the economy, especially with population inflow, are argued to have an impact on residents' quality of life. Because of the nature of rural areas, even a relatively small population inflow has the potential to affect the dynamics of a village. Other changes are more tangible, such as the 
construction of encapsulated rural gated communities (Spocter, 2013). Differences between residents and incomers can be maximized by both groups, giving expression to $u s$-them feelings (as part of othering or the process of transforming a difference into otherness). Fear of others is often one cause of the animosity between newcomers and locals, previously identified by Sandercock (2005) as an expression of the fear of the unknown.

Fear of "stranger danger" in public spaces has been much more engrained from childhood in women than in men. Therefore it is not odd that surveys show women declare feeling more unsafe than men do when on the move (Ceccato, 2013; Whitzman, 2007). Sandercock (2005) argues that expressions of fear are expressions of fear of difference. Sandercock (2000) claims that there is something about us that is in conflict with the stranger: "The stranger threatens to bring chaos into the known world... We must secure our centrality, and they who upset our homely space must be pushed out from the center. They are not like us and therefore they are threatening" (p. 205).

Many examples are found in the international literature. For example, Ruddell and Ortiz (2015) report how locals express concerns about reductions in quality of life (due to anti-social behavior, drug use, and aggressive, impaired, or dangerous driving) that the residents regard as a result of a large inflow of population into a Canadian rural town. In the United States, Hunter et al. (2002) assess the fear of crime across three categories of community residents with different migration histories in three rural boom municipalities: lifetime residents, migrants who joined the boomtown community during its period of rapid growth, and post-boom migrants. The authors find that boom migrants express greater fear of crime than longer-term residents or post-boom migrants. In a rapidly growing rural area in the United States, Crank, Giacomazzi, and Heck (2003) find that perceptions of drug and gang problems are associated with a wide variety of police order and crime problems. Fear of crime seems to incorporate what residents regard as cultural threats to their dominant constructions of rurality (Yarwood \& Gardner, 2000), which sometimes reveal hidden layers of intolerance and racism (Garland \& Chakraborti, 2006; Hubbard, 2005; Palmer, 1996). Norris and Reeves (2013) assess whether fear of crime represents itself differently according to the social environment in which it is experienced. They find that more authoritarian residents in a rural area are concerned about offenders traveling into their community to offend ("the danger is out there" feeling), whereas there were no differences among urban dwellers.

A homeless person is exposed to an increased risk of victimization and fear. Gaetz (2004) shows, for instance, that in Canada the conditions that place street youth at risk and cause fear are connected to such youths' experiences of social exclusion in terms of restricted access to housing, employment, and public spaces. Similarly, Gypsies and travelers in rural England face similar challenges in rural communities (Greenfields, 2014); such people are regarded as a constant source of anxiety for the locals but themselves feel a burden of exclusion. Targeted by the police when public order issues arise, travelers in the United 
Kingdom live with permanent feelings of fear from feeling out of place (Halfacree, 2011).

In England and Wales, exclusion of ethnic minorities from the life of rural communities is not the result of a monolithic entity (as described by Robinson and Gardner, 2012, p. 85) and takes different shapes, generating anxieties experienced on a daily basis (Robinson \& Gardner, 2012). In Australia, Scott et al. (2012) reveal how crime talk in a mining town is a result of specific social constructions and the relative ability of groups to act as a cohesive network, used in the power relations between locals and newcomers. In Sweden and Finland, Jensen (2012) illustrates how economic change in rural areas, dissatisfaction, and anxieties create fertile ground for the proliferation of xenophobic ideas, expressed by the advance of extreme-right-wing political parties in recent elections. Similar expressions of discrimination are reported among the young Sami population, a group that has historically been a minority in Scandinavia. For more details, see the next section of this chapter.

\section{Macro-societal changes}

Some contemporary anxieties are generated by a sense of loss of personal security imposed by changes that go far beyond the local community. The transition from "modernity" to "late modernity" (Giddens, 1991, pp. 70-88) or by the preeminence of the risk society (Beck, 2000) is said to cause major changes in our sense of safety. This is an ongoing process that occurs worldwide yet also produces local effects. These transformations, according to Bottoms and Wiles (2002), have had a direct effect on crime and fear of crime. In "late modernity," the moment in time that most characterizes what we are undergoing now, globalization is creating potential risks that concern all types of people. According to Beck (2000), "these dangers" cannot be socially delimited in either space or time. Thus, the potential threat eludes the control of institutions of society and cause feelings of anxiety about who is at risk or who is responsible for what. The challenge of catching international networks of organized crime is just one example of the challenges faced by authorities when trying to control the flow of people and money in a quasi-borderless Europe. Perhaps it is irrelevant, though, to attempt to quantify individuals' fear as an everyday life experience. More important to one's perceived safety is perhaps "fear attractors" that are quite mundane, daily life experiences or facts that make one anxious or worried but do not affect the individual directly (e.g., mass-media coverage of violence), and "fear generators," such as being victimized by a crime or seeing someone else become a victim of crime.

Victimization is an important fear generator, but anxieties may also be fed by an individual's uncertainties and frustrations in everyday life, such as being unemployed or having a sense of the gap between the individual's limited resources and society's overall unlimited opportunities for consumption (anomic conditions). As Hope and Sparks (2000, p. 5) suggest, fear of crime may "intersect with the larger consequences of modernity." Thus, as suggested by 
Hummelsheim, Hirtenlehner, Jackson, and Oberwittler (2010, p. 5), "if fear of crime can be both a specific concern about crime and a more general projection of a range of connected social anxieties, then fear of crime should be closely connected with feelings of social insecurity." The authors find evidence that European countries with high levels of social protection display low levels of fear whilst low levels of social protection show high levels of insecurity feelings, supporting the expected negative association between the extent of social protection and fear of crime.

Current anxieties are said to be generated by a lack of individuals' embedded biography with a plurality of social worlds, beliefs, and diversification of lifestyles that can be accessed by mass media via ICT. Some of these feelings relate to a lack of an individual's sense of order and continuity in regard to one's experiences in life (Giddens, 1991), being experienced as threats that can take different shapes. The perceived collective danger is a social construct fed by the attention put on its existence, either real or not. The increasing commodification of security (by proliferation of a market for personal security products and services), for instance, indicates that fear of crime is one of these contemporary perceived "dangers." Mass media coverage has an important role to play in this context, where the notion of "stimulus similarity" is suggested as important in explaining the reaction of fear (Winkel \& Vrij, 1990). When an individual reads a newspaper and identifies with the described victim or feels that his/her own community is similar to the one described in the news, then the image of risk may be taken up, personalized, and translated into personal safety concerns.

\section{Commodification of security}

Security as a public good in today's society is now delivered by a set of actors no longer limited to the police forces and relies on a broader project that depends on the interplay of different actors (some public, other private or neither) (Loader, 2000). Differential access to protection affects how risks are distributed among individuals, social groups, and places. In practice, this "materialization of fear does not only change the landscape for all, it reflects also a sharp unequal distribution of fear, privilege and risk" (Pain, 2009). As with any other commodity, the "safe feeling" cannot be purchased by all. Wilhelmsson and Ceccato (2015) show that house buyers in a rural municipality, as in large cities, are willing to pay more for dwellings that are less targeted by crime and disorder than for those located in criminogenic parts of a village. In extreme cases, the market for safety leads to the development of gated communities, even in rural areas (Macari, 2009; Spocter, 2013). As suggested by Goold, Loader, and Thumala (2010), although gated communities might be considered a failed good in Western Europe, the security industry in general is growing (Zedner, 2009). In countries such as South Africa and Brazil, the proliferation of rural gated developments has been linked to a market for consumers able to pay for exclusivity in an idyllic rural setting. These housing developments often offer other 
commodities that allow easy transport to urban centers, resembling the traditional features of garden cities. Thus, these housing projects are the product of wider processes of change in rural areas related to counter-urbanization and extraction of amenity value from the rural landscape (Macari, 2009; Spocter, 2013).

\section{Concluding remarks}

Are individuals living in the countryside less worried about crime than those living in urban areas? They might be, but in this chapter attempts were made to illustrate that the safety perceived by people living in rural areas is a more complex phenomenon than the one reflected in overall expressions of fear of crime.

Poor perceived safety may be triggered by previous victimization. Thefts of livestock from neighboring farms may mobilize local farmers to be proactive out of the fear that something will happen with their own livestock. Foreign women brought to rural Sweden may live in fear because they do not know their rights, whether they can seek help and assistance if isolated in remote areas.

Given the multifaceted nature of perceived safety and the complexity of fear of crime, a relevant question is: how can fear be informative to those living and working with safety issues in rural communities?

At an individual level, it is important to differentiate between a dysfunctional worry about crime that erodes quality of life and a functional worry that motivates vigilance and routine precaution (Jackson \& Gray, 2010). In Jackson and Gray's study, around one-quarter of research participants who said they were worried about crime and took precautions that made them feel safer also said they did not experience a reduction in quality of life as a result of their worry or cautionary activity. Adopting measures that aim at reducing both risk and worry about victimization by different groups of society seems to be central.

Crime prevention measures are traditionally used to reduce crime risk and consequently fear of crime. For instance, tackling crime through the situational conditions of crime in some cases has had a proven impact on perceived safety combined with long-term social crime prevention. Actions to improve safety have to be inclusive and avoid stigmatizing those who are already in a disadvantaged position in society. For this to happen, actors must be aware of their roles and the challenges involved when working with specific safety issues embedded in particular contexts. They should strive to work toward practices that are inclusive and fair (different target groups but also based on a coalition of different actors) and, as much as possible, to work within participatory frameworks. The process of discussing local fears and sources of anxiety demands an open and communicative process, involving negotiation and mediation to work through these fears with those directly affected.

In a neutral world, both crime and protection from victimization would be evenly distributed in society. With the commodification of security, preventing 
crime implies costs for the individual and society in general. As with any other commodity, security is not evenly obtained by all, which inevitably generates inequalities in victimization and perceived safety. Perceived safety as an individual right entails a dimension of reflexivity, which means that it depends on those who observe and produce it. Not all people would agree that the problem is worthy of attention, and most may disagree that particular action is needed, but the process of bringing people together can itself make parties talk through their concerns. Such an approach requires communicative skills among those who take part in the process, a process that, in the best of worlds, should be sensitive to gendered fear as well as a cross-cultural understanding of the fears. Thus, the main task for those working to improve perceived safety is perhaps to identify the sources of anxiety and mediate possible alternatives for action that can make those involved feel informed and, finally, safer.

The implication of this is that there is no such thing as a remedy that can solve the problems of crime and perceived safety, let alone a single actor (such as the police) that can tackle problems. It is submitted here that perceived safety is a collective project that requires constant assessment by those who produce it: those who are in fear, the community itself, stakeholders. Perceived safety is both the cause and the product of people's everyday life practices and experiences, embedded in a context that is not politically neutral, or limited to the village, rural areas, or individual nations. At the same time, there is no doubt that some tangible attributes of perceived safety stem from local rural conditions, where daily anxieties arise from victimization, discrimination, economic change, and many other root causes of fear.

The approach that would seem to make sense, given the discussion in the previous section, is for local communities to organize themselves around problems of perceived safety that cause them concern. These actions can enhance existing models of participation to develop culture- and gender-informed governance structures that give voice to those who feel unsafe. The definition of priorities to be dealt with must adhere to limits that take into account realistic goals. An isolated and remote location can be an advantage and a motivation for rural communities in searching for more appropriate solutions to local problems, such as the sources of fear. Fear is not a problem to be solved or that can be solved in the same way as crime. Given the multifaceted nature of fear, some sources of anxiety cannot be tackled at the level of those who fear. Some declared fears or anxieties are a tiny fraction of the old and new challenges faced by groups in the community and by those who may spend some time there, as in the case of temporary workers. Signs of relatively poor mobility among certain groups, as shown in this chapter, can be used as a reference that could guide future efforts to tackle the structural causes of fear and other anxieties. 


\section{Perceived safety in rural areas}

\section{References}

Acuña-Rivera, M., Brown, J., \& Uzzell, D. (2014). Risk perception as mediator in perceptions of neighbourhood disorder and safety about victimisation. Journal of Environmental Psychology, 40(0), 64-75.

Bankston, W. B., Jenkins, Q. A., Thayer-Doyle, C. L., \& Thompson, C. Y. (1987). Fear of criminal victimization and residential location: The influence of perceived risk. Rural Sociology, 52(1), 98-107.

Barclay, E., Scott, J., Hogg, R., \& Donnermeyer, J. (Eds.). (2007). Crime in rural Australia. Sydney: Federation Press.

Beck, U. (2000). The cosmopolitan perspective: Sociology of the second age of modernity. British Journal of Sociology, 51(1), 79-105.

Bergström, G. (2008). Ett könsperspektiv på resor i arbetet. Arbetsmarknad \& Arbetsliv, 4(2), 29-50.

Bottoms, A. E., \& Wiles, P. (2002). Environmental criminology. In R. M. M. Maguire, \& R. Reine (Eds.), The Oxford handbook of criminology (pp. 620-656). Oxford: Oxford University Press.

Box, S., Hale, C., \& Andrews, G. (1988). Explaining fear of crime. British Journal of Criminology, 28, 340-356.

Bradford, B., \& Myhill, A. (2015). Triggers of change to public confidence in the police and criminal justice system: Findings from the Crime Survey for England and Wales panel experiment. Criminology and Criminal Justice, 15(1) 23-43.

Bromley, R. D. F., \& Nelson, A. L. (2002). Alcohol related crime and disorder across urban space and time: Evidence from a British city. Geoforum, 33, 239-254.

Brottsförebyggande rådet - BRÅ (National Council of Crime Prevention). (2011). The national victims survey. Stockholm: BRÅ.

Cancino, J. M. (2005). the utility of social capital and collective efficacy: Social control policy in nonmetropolitan settings. Criminal Justice Policy Review, 16(3), 287-318.

Canter, D., \& Larkin, P. (1993). The environmental range of serial rapists. Journal of Environmental Psychology, 13, 63-69.

Cates, J. A., Dian, D. A., \& Schnepf, G. W. (2003). Use of protection motivation theory to assess fear of crime in rural areas. Psychology, Crime and Law, 9(3), 225-236.

Ceccato, V. (2013). Moving safely: Crime and perceived safety in Stockholm's subway stations. Plymouth: Lexington.

Ceccato, V. (2014). The nature of rape places. Journal of Environmental Psychology, 40, 97-107.

Ceccato, V., \& Dolmén, L. (2013). Crime prevention in rural Sweden. European Journal of Criminology, 10, 89-112.

City of Stockholm (2011). Trygg i Stockholm? 2011 En stadsövergripande trygghetsmätning. Stockholm: City of Stockholm, Social care.

Crank, J. P., Giacomazzi, A., \& Heck, C. (2003). Fear of crime in a nonurban setting. Journal of Criminal Justice, 31(3), 249-263.

Day, K. (2009). Being feared: Masculinity and race in public space. In M. L. S. Farrall (Ed.), Fear of crime: Critical voices in an age of anxiety (pp. 82-107). New York: Routledge-Cavendish.

DeKeseredy, W. S., \& Schwartz, M. D. (2008). Separation/divorce sexual assault in rural Ohio: Survivors' perceptions. Journal of Prevention and Intervention in the Community, 36(1), 105-119. 
Donnermeyer, J., \& Kreps, G. M. (1986). The benefits of crime prevention: A comparative analysis. Columbus, $\mathrm{OH}$ : National Rural Crime Prevention Center.

Ferraro, K. F. (1995). Fear of crime: Interpreting victimization risk. Albany, NY: State University of New York Press.

Furstenberg, J. F. F. (1971). Public reaction to crime in the streets. American Scholar, 40(40), 601-610.

Fyhri, A., \& Backer-Grøndahl, A. (2012). Personality and risk perception in transport. Accident Analysis and Prevention, 49, 470-475.

Gaetz, S. (2004). Safe streets for whom? Homeless youth, social exclusion, and criminal victimization. Canadian Journal of Criminology and Criminal Justice/La Revue canadienne de criminologie et de justice pénale, 46(4), 423-456.

Garland, J., \& Chakraborti, N. (2006). "Race", space and place: Examining identity and cultures of exclusion in rural England. Ethnicities, 6(2), 159-177.

Garofalo, J., \& Laub, J. (1979). Fear of crime: Broadening our perspective. Victomology, 3, 242-253.

Giddens, A. (1991). Modernity and self-identity: Self and society in the late modern age. Cambridge: Polity Press.

Gil Sola, A. (2010). Regionförstoring innebär längre restider för både kvinnor och män. Plan, 2, 13-17.

Goold, B., Loader, I., \& Thumala, A. (2010). Consuming security? Tools for a sociology of security consumption. Theoretical Criminology, 14(1), 3-30.

Gray, D. E., \& O'Connor, M. (1990). Concern about and fear of crime in an Australian rural community. Australian and New Zealand Journal of Criminology, 23, 284-298.

Greenfields, M. (2014). Gypsies and travellers in modern rural England. In G. Bosworth \& P. Somerville (Eds.), Interpreting rurality: Multidisciplinary approaches (pp. 219-234). London/New York: Routledge.

Hale, C. (1996). Fear of crime: A review of the literature. International Review of Victimology, 4, 79-150.

Halfacree, K. (2011). Still "Out of place in the country"? Travellers and the postproductivist rural. In R. I. Mawby \& R. Yarwood (Eds.), Rural policing and policing the rural: A constable countryside? (pp. 124-135). Farnham: Ashgate.

Hayman, S. (2011). Older people in Canada: Their victimization and fear of crime. Canadian Journal on Aging/La Revue canadienne du vieillissement, 30(3), 423-436.

Hofferth, S. L., \& Iceland, J. (1998). Social capital in rural and urban communities. Rural Sociology, 63(4), 574-598.

Hope, T., \& Sparks, R. (2000). Crime, risk, and insecurity: Law and order in everyday life and political discourse. London: Routledge.

Hubbard, P. (2005). "Inappropriate and incongruous": Opposition to asylum centres in the English countryside. Journal of Rural Studies, 21(1), 3-17.

Hummelsheim, D., Hirtenlehner, H., Jackson, J., \& Oberwittler, D. (2010). Social insecurities and fear of crime: A cross-national study on the impact of welfare state policies on crime-related anxieties. European Sociological Review, 27(3), 327-345.

Hunter, L. M., Krannich, R. S., \& Smith, M. D. (2002). Rural migration, rapid growth, and fear of crime. Rural Sociology, 67(1), 71-89.

Jackson, J., \& Gray, E. (2010). Functional fear and public insecurities about crime. British Journal of Criminology, 50(1), 1-22.

Jensen, M. (2012). Rasism, missnöje och "fertile grounds" Östergötland Sverige jämförs med Birkaland Finland: Sverigedemokraterna vs Sannfinländarna (Master's degree, Linköping University, Linköping). 


\section{Perceived safety in rural areas}

Koskela, H. (1999). Fear, control and space: Geographies of gender, fear of violence, and video surveillance ( $\mathrm{PhD}$, University of Helsinki, Helsinki).

Kunieda, M., \& Gauthier, A. (2007). Gender and urban transport: Fashionable and affordable. Sustainable transport: A sourcebook for police makers in developing cities. Eschborn: GTZ.

Lagrange, R. L., \& Ferraro, K. F. (1989). Assessing age and gender diferences in perceived risk and fear of crime. Criminology, 27(4), 697-720.

LaGrange, R. L., Ferraro, K. F., \& Supancic, M. (1992). Perceived risk and fear of crime: Role of social and physical incivilities. Journal of Research in Crime and Delinquency, 29(3), 311-334.

Landman, K. (2012). Reconsidering crime and urban fortification in South Africa. In V. Ceccato (Ed.), The urban fabric of crime and fear (pp. 239-264). Dordrecht: Springer.

Lewis, D. A., \& Maxfield, M. G. (1980). Fear in the neighborhoods: An investigation of the impact of crime. Journal of Research in Crime and Delinquency, 17(2), 160-189.

Loader, I. (2000). Plural policing and democratic governance. Social and Legal Studies, 9(3), 323-345.

Lorenc, T., Petticrew, M., Whitehead, M., Neary, D., Clayton, S., Wright, K., Thomson, H., Cummins, S., Sowden, A., \& Renton, A. (2013). Fear of crime and the environment: Systematic review of UK qualitative evidence. BMC Public Health, 24(13), 496.

Los, M. (2002). Post-communist fear of crime and the commercialization of security. Theoretical Criminology, 6(2), 165-188.

Lotz, R. (1979). Public anxiety about crime. Pacific Sociological Review, 22(2), 241-254.

Loukaitou-Sideris, A. (2004). Is it safe to walk here? Paper presented at the Conference Proceedings Research on Women's Issues in Transportation. Chicago, IL.

Macari, A. C. (2009). Condominios fechados em areas rurais: O caso de Rancho Queimado na Região Metropolitana de Florianópolis (Master's degree, Universidade de Florianopolis, Florianopolis, Brazil).

Marshall, B., \& Johnson, S. (2005). Crime in rural areas: A review of the literature for the rural evidence research centre. Jill Dando Institute of Crime Science, University College, London.

Maxfield, M. G. (1984). Fear of crime in England and Wales. London: Home Office, Research and Planning Unit.

Milgram, S. (1974). The experience of living in cities. In C. M. Loo (Ed.), Crowding and behavior (pp. 41-54). New York: MSS Information Cooperation.

Newman, O. (1972). Defensible space: Crime prevention through urban design. New York: Collier Books.

Norris, G., \& Reeves, H. (2013). Fear of crime and authoritarianism: A comparison of rural and urban attitudes. Crime Prevention and Community Safety, 15(2), 134-150.

Pain, R. (2009). Critical geopolitics and everyday fears. In M. Lee \& S. Farrall (Eds.), Fear of crime: Critical voices in an age of anxiety (pp. 45-58). New York: RoutledgeCavendish.

Pain, R., \& Smith, S. J. (2008). Fear: Critical geopolitics and everyday life. In R. Pain \& S. J. Smith (Eds.), Fear: Critical geopolitics and everyday life (pp. 1-24). Aldershot: Ashgate.

Palmer, D. L. (1996). Determinants of Canadian attitudes toward immigration: More than just racism? Canadian Journal of Behavioural Science/Revue canadienne des sciences du comportement, 28(3), 180-192.

Panelli, R., Little, J. O., \& Kraack, A. (2004). A community issue? Rural women's feelings of safety and fear in New Zealand. Gender, Place and Culture, 11(3), 445-467. 
Pyle, G. (1974). The spatial dynamic of crime. Chicago, IL: Department of Geography, University of Chicago.

Robinson, V., \& Gardner, G. (2012). Unravelling a stereotype: The lived experience of black and minority ethnic in rural Wales. In N. Chakraborti \& J. Garland (Eds.), Rural racism (pp. 85-107). Abingdon/New York: Routledge.

Ruddell, R., \& Ortiz, N. (2015). Boomtown blues: Long-term community perceptions of crime and disorder. American Journal of Criminal Justice, 40, 129-146.

Sampson, R. J., Morenoff, J. D., \& Felton, E. (1999). Beyond social capital: Spatial dynamics of collective efficacy for children. American Sociological Review, 64(5), 633-660.

Sampson, R. J., \& Raudenbush, S. W. (2004). Seeing disorder: Neighborhood stigma and the social construction of "broken windows". Social Psychology Quarterly, 67(4), 319-342.

Sandercock, L. (2000). When strangers become neighbours: Managing cities of difference. Planning Theory and Practice, 1(1), 13-30.

Sandercock, R. J. (Ed.). (2005). Difference, fear and habitus: A political economy of urban fear. Aldershot: Ashgate.

Scott, J., Carrington, K., \& McIntosh, A. (2012). Established-outsider relations and fear of crime in mining towns. Sociologia Ruralis, 52(2), 147-169.

Shappland, J., \& Vagg, J. (1985). Social control and policing in rural and urban areas. Oxford: Centre for Criminological Research, University of Oxford.

Skogan, W. G. (1987). The impact of victimization on fear. Crime and Delinquency, $33(1), 135-154$.

Skogan, W. G. (1996). The police and public opinion in Britain. American Behavioral Scientist, 39(4), 421-432.

Skogan, W. G., \& Maxfield, M. G. (1981). Coping with crime: Individual and neighborhood reactions. Thousand Oak, CA: Sage.

Skår, M. (2010). Forest dear and forest fear: Dwellers' relationships to their neighbourhood forest. Landscape and Urban Planning, 98(2), 110-116.

Spocter, M. (2013). Rural gated developments as a contributor to post-productivism in the Western Cape. South African Geographical Journal, 95(2), 165-186.

Torstensson, G., Forslund, M., \& Tegnell, A. (2011). Förslag till nationell handlingsplan för säkerhetsfrämjande arbete för äldre personer (Vol. 12, p. 48). Stockholm: Socialstyrelsen.

Tönnies, F. (1887). Gemeinschaft und Gesellschaft. Leipzig: Fues's Verlag. (Translated, 1957 by Charles Price Loomis as Community and society, East Lansing, MI: Michigan State University Press.)

Valentine, G. (1990). Women's fear and the design of public space. Built Environment, 16(4), 288-303.

Warr, M. (2000). Fear of crime in the United States: Avenues for research and policy. Criminal Justice and Behavior, 4, 451-489.

Whitzman, C. (2007). Stuck at the front door: Gender, fear of crime and the challenge of creating safer space. Environment and Planning A, 39(11), 2715-2732.

Wilhelmsson, M., \& Ceccato, V. (2015). Challenging the idyll: Does crime affect property prices in Swedish rural areas? Journal of Rural Studies, 39 (in press).

Wilson, J. Q., \& Kelling, G. L. (1982). Broken windows. Atlantic Monthly, 249, 29-38.

Winkel, F. V., \& Vrij, A. (1990). Fear of crime and mass media crime reports testing similarity hypotheses. International Review of Victimology, 1(3), 251-265.

Wretstrand, A., \& Svensson, H. (2008). Resmöjligheter i medelstora städer: närhet avgörande för mobilitet På rätt spår? - om tillgängliga resor för äldre och funktionshindrade. Lund: Teknik och Samhälle. 


\section{Perceived safety in rural areas}

Wyant, B. R. (2008). Multilevel impacts of perceived incivilities and perceptions of crime risk on fear of crime: Isolating endogenous impacts. Journal of Research in Crime and Delinquency, 45(1), 39-64.

Yarwood, R., \& Gardner, G. (2000). Fear of crime, cultural threat and the countryside. Area, 32(4), 403-411.

Zedner, L. (2009). Security. London: Routledge. 